\title{
The Opportunity of Vocational Technology Education Study Program: Curriculum Development and Learning Program
}

\author{
Riana Tangkin Mangesa, Abdul Muis Mappalotteng, Ruslan \\ Engineering Faculty \\ Universitas Negeri Makassar \\ Makassar, Indonesia \\ riana.tangkin@umm.ac.id
}

\begin{abstract}
Efforts to improve the learning program to support the revitalization of vocational education is an opportunity for vocational technology education (PTK) study program. The purpose of this research is to analyze the potential of PTK study program in preparing the learning program and the ability to develop the curriculum through survey method with students population of PTK and sample taken by purposive stratified. Data collection was done through documents and instrument studies (questionnaire). Data analysis was done descriptively with descriptive statistic. The results of research were (a) learning system and supporting facilities are very high; (b) learning programs and approaches also show high categories.
\end{abstract}

Keywords-vocational technology education study program, learning system, curriculum development

\section{INTRODUCTION}

The institutional curriculum is a number of study materials that are drawn up referring to the vision and characteristics of Higher Education adapted to the main competencies, support and other competencies of an institution of study program and is a differentiator in a similar study program between universities.

Technology and Vocational Education (PTK) is a master study program in Universitas Negeri Makassar (UNM), is the fourteenth study program organized under the operational permit from the Directorate of Higher Education Ministry of Education and Culture No. 310/E/O/2012.

The PTK study program is one of several study programs including the Teachers Training Institute (LPTK) and education manager, organizing master's degree program in Technology and Vocational Education, aiming to produce prospective teachers who are generally SMK teachers.

Referring to the vision of study program, PTK as a reference for the development of master education, with its functions and duties as a qualified Technology and Vocational Education institution in accordance with the academic and / or professional nature of vocational technology education, which has expertise and capable of producing superior human resources, means for the development of the nation and humanity. The success of vocational education institutions is different from general education.

This framework takes advantage of extensibility and customizability by providing the possibility of flexible system configuration. Thus, supporting a new learning scenario or customizing an existing scenario is equivalent to providing a new system configuration or adjusting an existing configuration [1].

The criteria for determining the success of a vocational education institution basically apply a double measure, namely in-school success and out-of-school success. These criteria are: (a) covering aspects of success in meeting the curricular requirements that have been oriented to the requirements of the world of work; (b) indicated by the success or appearance of graduates after being in the real world of work, and outcomes of vocational education [2].

To improve the professionalism of teachers requires some professional guidance systems that support the establishment of a human resource system in an institution. Thus, efforts to improve the strengthening of human resources in the field of education is to improve the ability of teachers, urging professionals as teachers to improve the ability to innovate, because teachers as the spearhead of learning implementers in schools.

Human resource development can be done through formal (school) and non formal education although human resource development efforts are not only done through schools, but are seen as a means of development and improvement of systematic, programmatic and tiered human resources.

The terms of learning according to some experts [3] [4], is a series of activities deliberately created to facilitate the learning process or series of events conveyed in a planned manner through a learning approach. Learning is a process done to gain new behavioral changes, as a result of interaction with the environment. Learning activities involve: (a) the teaching aspects of the teacher, regarding the planned learning process, (b) the students' learning aspect; the desired learning objectives achieved through the learning process.

The results of [5] structural equation modelling indicated that when teachers perceived their schools as being stronger in collegiality and more supportive of teacher competence and autonomy, they had higher motivation in project-based learning and stronger willingness to persist in this educational innovation,

Therefore, in the process of learning the material submitted must refer to the indicators that have become 
learning objectives. Thus, activities aimed at everything done in the learning process should be directed to achieve the goals that have been determined.

Moreover, in learning process, teachers need to pay attention that students should have many potential in critical and creative thinking, [6]. Because in the classroom learning, explaining the content of the material requires integration with the means of the situation in a supportive society.

The demand for changes the reorientation of vocational education in Indonesia in connection with Presidential Instruction No. 9 of 2016 on revitalization program of SMK, which aims to improve the quality and competitiveness of human resources in Indonesia. Changes through fundamental and thorough assessment both in the learning approach, reformulation of the roles of teachers and students of vocational schools, development approaches, evaluation of learning.

Competency changes can occur thoroughly in both the learning approaches, the reformulation of the roles of teachers and vocational school students, vocational education development approaches, and learning evaluations

The concept of competency-based learning requires the formulation of competencies that must be possessed by students after participating in learning activities, [7]. Furthermore, if a good assessment system will encourage teachers to determine a good teaching strategy and motivate students to learn better.

Teachers who are reliable, professional and highly competitive, and have strong professional skills are the basic capital in realizing quality education. To improve the professionalism of teachers some professional guidance systems that support the establishment of a human resource system in a country are required. Thus, a professional teacher improves the ability to innovate, educate and convey information, because teachers are the spearhead of learning in the school.

Based on Law No. 14 of 2005 on Teachers and Lecturers, Article 10 paragraph, which stated that the competence of teachers includes pedagogic competence, personality competence, social competence, and professional competence. Thus, the management of learning includes the design of learning and learning programs.

Referring to the decree of the Minister of National Education 232/2000 and 045/2002 which regulate the curriculum of Higher Education, to the 4 pillars of education that UNESCO advises in the face of the 21 st century which consists of a core curriculum that is main competence of a particular study program established by mutual agreement between the professional community and stakeholder between $40-80 \%$.

Thus, curriculum changes must take place in college, change occurs solely in order to adapt to the times. To achieve this, it is necessary to improve the quality of learning. The curriculum for universities refers to the Indonesian National Qualification Framework (KKNI) curriculum, the skeleton of competence qualification that matches, integrates education and job training, work experience on the of job competence recognition.
According to [8], the core of learning process in vocational school is training. In preparing training programs in SMK, they should pay attention to the impact they will face, instructional methods and media that enable learners gain new knowledge and skills.

One of the main principles understood in the curriculum of KKNI is the change in the learning process in the learning outcomes, which is based on the mastery of the content of study, science, able to apply and develop in interpreting its role as a college graduate. Curriculum development aims at developing materials/ contents, strategies / methods, and evaluation consisting of nine levels, starting from qualification first as of the highest qualification. Qualification level is a nationally agreed learning achievement level, based on the educational outcome and training obtained through formal, non-formal, informal, or work experience.

The learning process contains two elements, namely process and learning outcomes. The process is an activity to achieve the purpose of teaching, while learning outcomes are the efforts of the ability of students after receiving the learning experience. In relation to the main principle of curriculum change, understood in the curriculum of KKNI, that vocational technology education refers to the competence of learning outcomes. So the problem arises, how do the PTK study program prepare the learning program and develop curriculum according to KKNI?

\section{METHOD}

\section{A. Research Design}

The research method used was descriptive survey with student population of PTK, sample taken at random. Techniques and data collection tools used, observations, instruments (questionnaires) of respondents using a Likert scale. According to [9] Likert Scale is used to measure the opinions and perceptions of a person or group of people about social phenomena. Data collection, lecturers and number of lecturers teaching, related to the research problem. Statistical analysis using IBM SPSS Statistics 20 software.

\section{B. Sample Size and Sampling Technique}

The population in this study were all the students of PTK, the sample size was 63 people, randomly assigned from the third semester students chosen because it was considered already completed the course of the skill program and had written the research proposal.

\section{Instrument}

The research instrument was developed based on the lattice grid of the instrument which refers to aspects of curriculum development and aspects of the learning program. Instrumentation validated Judgement, the purpose of validation is to assess the feasibility of the instrument, avoiding unclear statements, considering the addition and subtraction of item statements. The validation of validated instrument results, disseminated to the respondents

\section{Data Analysis}

In this study, alternative questionnaire answers set the scores given on each option by using Likert scale modification. Thus, the respondent in answering the 
statement there are only 4 categories; strongly agree (SS), agree (S), disagree (TS), strongly disagree (STS), of answer, have the value of the score with the details as follows, Table I.

TABLE I. THE SCORE VALUE

\begin{tabular}{|c|c|c|}
\hline No & Question & Score \\
\hline 1 & strongly agree & 4 \\
\hline 2 & agree & 3 \\
\hline 3 & disagree & 2 \\
\hline 4 & strongly disagree & 1 \\
\hline
\end{tabular}

To describe the suitability of existing supporting facilities and learning systems, the categories are made into four categories: Very High, High, Low, Very Low, modified, [10].

\section{RESULT AND DISCUSSION}

\section{A. Learning System and Supporting Facilities}

The results of the study for learning systems and supporting facilities, shown by the data obtained from the indicators of the distribution of statements in the data analysis group in Table II.

TABLE II. INDICATORS LEARNING SYSTEM AND SUPPORTING FACILITIES

\begin{tabular}{|l|c|c|c|c|c|c|}
\hline \multirow{2}{*}{ Category } & \multicolumn{3}{|c|}{ Frequency } & \multicolumn{3}{c|}{ Percentage (\%) } \\
\cline { 2 - 7 } & $\mathbf{1}$ & $\mathbf{2}$ & $\mathbf{3}$ & $\mathbf{4}$ & $\mathbf{5}$ & $\mathbf{6}$ \\
\hline Very High & 28 & 26 & 46 & 44.5 & 41.27 & 73 \\
\hline High & 33 & 37 & 14 & 52.3 & 58.73 & 22.2 \\
\hline low & 2 & 0 & 3 & 3.2 & 0 & 4.8 \\
\hline Very low & 0 & 0 & 0 & 0 & 0 & 0 \\
\hline & 63 & 63 & 63 & 100 & 100 & 100 \\
\hline
\end{tabular}

Explanation:

Frequency

1. Learning Facilities

2. Learning Resource

3. Intensity of Learning Process

Percentage

4. Learning Facilities

5. Learning resources

6. Intensity of Learning Process

The results of statistical analysis showed the highest score of 67, the lowest score of 16 with interval of 12, spread over 4 categories which were Very High, High, low Very low, as in Table II. The data in Table II shows the relationship between the availability of learning facilities, learning resources and learning intensity.

Figure 1 is histogram result of data analysis, which is a description of data about the relationship of learning systems and supporting facilities that exist in the study program PTK PPs Makassar State University.

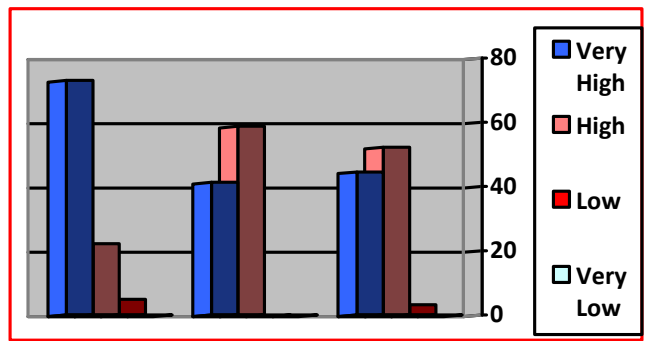

Fig. 1. Description of Learning System and Supporting Facilities

The result of the research shown in Fig. 1 is a description of the potential of learning system and supporting facilities in PTK PPs UNM study program. The potential was in a very high category, supported by indicators of data that spread to the group of high learning facilities, high learning resources and the intensity of the learning process was very high. This indicator showed the readiness of the PTK study program.

Lecturers who are an important component of the learning program, as the educational staff have the main task in the implementation of learning, quality to improve the quality of education. Students involved in the intensity of a very high learning process showed motivation in responsibility as a prospective professional teacher.

Achievements were maximum due to the support of facilities and infrastructure. So that the linkage of learning and the means of very need the main priority on the potential of the study program. According to [11], infrastructure is everything that supports both directly and indirectly to the smooth process of learning. such as learning media, learning tools, school supplies and so fort.

\section{B. Learning Program and Learning Approach}

The results of research on learning programs and learning approaches, shown by the data obtained from the indicator distribution statement in the group, the results of data analysis can be seen in Table III. Both of these indicators showed the link.

TABLE III. LEARNING PROGRAM AND LEARNING APPROACHES

\begin{tabular}{|l|c|c|c|c|c|c|}
\hline \multirow{2}{*}{ Category } & \multicolumn{2}{|c|}{ Interval } & \multicolumn{2}{c|}{ Frequency } & \multicolumn{2}{c|}{$\begin{array}{c}\text { Percentage } \\
\text { (\%) }\end{array}$} \\
\cline { 3 - 7 } & \multicolumn{2}{|c|}{} & $\mathbf{1}$ & $\mathbf{2}$ & $\mathbf{3}$ & $\mathbf{4}$ \\
\hline Very High & 98 & 120 & 37 & 25 & 58.7 & 39.7 \\
\hline High & 75 & 97 & 24 & 32 & 38.1 & 50.8 \\
\hline low & 52 & 74 & 2 & 6 & 3.2 & 9.5 \\
\hline Very low & 29 & 51 & 0 & 0 & 0 & 0 \\
\hline & & 63 & & 100 & \\
\hline
\end{tabular}

Explanation:

Frequency

1. Learning Program

2. Learning approaches

Percentage

3. Learning Program

4. Learning approaches 
Based on Table III, it was found that the learning program data on the category was very high $58.7 \%$, and the learning approaches in the high category was $39.7 \%$.

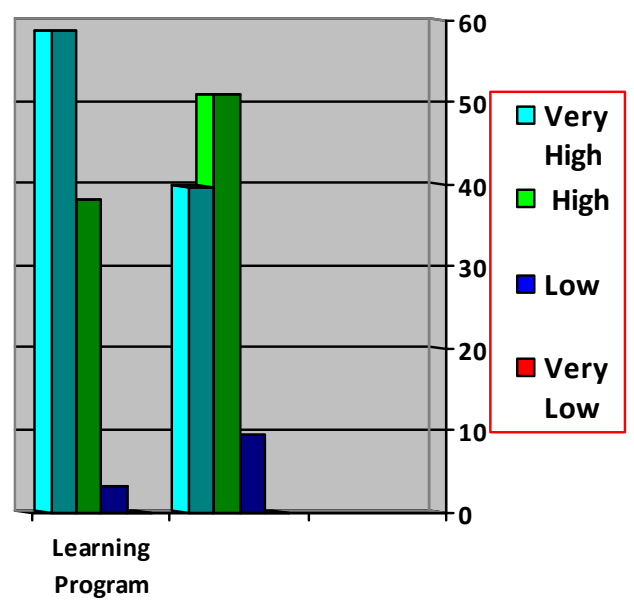

Fig. 2. Description of Learning System and Learning approaches

Fig. 2 is histogram result of data analysis, description, the relation of Learning system and Supporting Facilities exist in PTK PPs program study of Universitas Negeri Makassar. Therefore, the existing program in the curriculum becomes a guide in learning planning between learning program and learning approaches.

The result of the research in Figure 2 shows the comparison of the program of overview and learning approach by the lecturer in the learning process. Being a proof that the learning program, is a guide in making learning innovations.

Creativity and innovation are prerequisite for survival in education, even more needed according to technological developments. Companies owned and responded to economic pressures and increased competition by encouraging innovation and creativity to achieve success [12].

A program can be understood as a group of activities intended to achieve the goal. Thus, it should also be noted that there is a strong emphasis in the literature on the difference between career counseling and job matching services, with experience using a client-centered development approach that aims to enable individuals to manage their own career paths and learning [13].

\section{CONCLUSION}

. The results of research were learning system and supporting facilities are very high. Learning programs and approaches also show high categories.

\section{REFERENCES}

[1] Denis Helic,"Formal Representations of Learning Scenarios: A Methodology to Configure E-Learning Systems" Journal of Universal Computer Science, vol. 13, no. 4. 2007. http://citeseerx.ist.psu.edu/viewdoc/doi=10.1.1.116.8100\&rep=rep1\& type=pdf.

[2] Sukamto,"Perubahan Karakteristik Dunia Kerja dan Revitalisasi Pembelajaran dalam Kurikulum Pendidikan Kejuruan", Pidato pada Rapat Terbuka Senat Universitas Negeri Yogyakarta, 2001.

[3] Gagne, Robert M. Principles of Instructional Design. New York: Wasdworth Publishing Co.2005.

[4] Dick, Walter \& Carey, Lou., Carey, James O. "The Systematic Design Of Instruction (5 thed). New York: Longman, 2001.

[5] Shui-fong Lam;Rebecca Wing-yi Cheng;Harriet C. Choy.School support and teacher motivation to implement project-based learning. Elsevier Ltd. All rights. reserved.doi:10.1016. 2009.

[6] R.T Mangesa, Dyah D. A, "The Effectiveness of Media Implementation in Competence-Based Learning Integrated With Character Building in Vocational High Schools" Proceedings of the 3rd UPI International Conference on TVET, https://www.atlantispress.com/proceedings/tvet4/articles?q=riana+ma ngesa

[7] Syahrul and R.T. Mangesa,"Development of Dacum as Identification Technique on Job Competence Based-Curriculum in High Vocational Education" IOSR-JRME e-ISSN: 2320-7388,p-ISSN:2320 737XVolume 5, Issue 2 Ver.I,2015.http://www.iosrjournals.org/-iosrjrme/papers/Vol-5\%20Issue-2/Version-1/I05214448.pdf

[8] Balqis, Putri, "Kompetensi Pedagogik Guru dalam Meningkatkan Motivasi Belajar Siswa Pada SMPN3".Jurnal Administrasi Pendidikan Pascasarjana Universitas Syiah Kuala, Vol 2, No.1. pp 2538, 2014.

[9] Sugiyono, Metode Penelitian, Bandung: CV Alfa Beta, 2013.

[10] Slameto,"Evaluasi Pendidikan",Jakarta: Bumi Aksara, 2001.

[11] Sanjaya Wina, "Strategi pembelajaran berorientasi standar proses pendidikan. Jakarta: Kencana Prenada Media Group, 2010.

[12] Hijazi Sam, Smith M., Leigh, Vazquez, E.A.. "Creative ProblemSolving Software and Portals" Seeker A. Campus. Key West, Florida 33040(305), 2004.

[13] Francesca Beddie, Barb Lorey, Barbara P., Enhancing career development The role of community-based career guidance for disengaged adults. Published by NCVER. ABN 87007967311. 2005. 